\title{
Split tibialis anterior tendon transfer to treat ambulatory children with spastic cerebral palsy who experienced dynamic equino varus deformity.
}

\author{
Omer Ali Rafiq Barawi ${ }^{1}$; Zmnako Jamal Amen ${ }^{2}$ \\ 1 MBChB, FICMS- Orthopaedics, MDOA the Netherlands, Department of Surgery, University of Sulaimani / College of Medicine, \\ Sulaymaniyah city, Kurdistan Regional Government of Iraq \\ 2 MSc in Biophysics RuG in Groningen, the Netherlands, Department of Physiology, University of Sulaimani / College of \\ Medicine, Sulaymaniyah city, Kurdistan Regional Government of Iraq
}

Received: 06.10.2020

Accepted: 23.01.2021

\begin{abstract}
Treatment of ambulatory children with spastic cerebral palsy complaining from dynamic equino varus deformity by split tibialis anterior tendon transfer (STATT), because over activity of tibialis anterior muscle and weak antagonist muscles are the main cause of the deformity. The purpose of this study is to assess the postoperative results of split tibialis anterior tendon transfer, according to Garceau and Palmer criteria.

Methods: 13 feet in 13 ambulatory children with spastic cerebral palsy complaining from dynamic equino varus deformity brought to the hospital by their parents, preoperatively 7 of the fair, 6 of them were poor, while postoperatively 2 of them became excellent, 10 of them good and 1 of the fair. Their ages ranged from 4-8 years old, and average 4.9 years.

Results: The result of this prospective case series study assessed by using Garceau and Palmer criteria, which improved from 1.54 point preoperatively to 3.08 pints post operatively.

Conclusion: Split tibialis anterior tendon transfer, is a good method for treating ambulatory children with spastic cerebral palsy complaining of dynamic equinovarus deformity of the forefoot and midfoot which is due to overactivity of tibialis anterior muscle and weak antagonists.
\end{abstract}

Keywords: Dynamic equinovarus foot deformity; Split tibialis anterior tendon transfer; Hoffer's procedure; and Garceau \& Palmer criteria.

Corresponding to:

Omer Ali Rafiq Barawi, Department of Surgery, University of Sulaimani / College of Medicine, Sulaymaniyah city, Kurdistan Regional Government of Iraq

o_barawi@hotmail.com

Phone No.: + +964 7701516360

\section{Introduction}

Cerebral palsy is a static encephalopathy defined as a non-progressive disorder of posture and movement $1,2,3,4$. Cerebral palsy was first described by William Little's in 1862 and called
Little's disease $\mathrm{e}^{5,6,7,8,9}$. In 1974 Hoffer et al. first described split tibialis anterior tendon transfer to correct supination and varus deformity of the mid foot secondary to spasticity of the anterior tibial muscle $^{9,10}$. The result of the current study is assessed according to Garceau and Palmer criteria, which is based on the presence or absence of metatarsus adducts, heel varus and equinus. A normal appearing foot other than being smaller than the opposite foot was considered as an excellent result (4 points). Mild deformity in one or two parameters a good result (3 points), moderate deformity in all three 
parameters a fair result ( 2 points), and a sever deformity in all three parameters a poor result (1 point $)^{11,12,13}$.

We have done this study in order to evaluate the operative results of split tibialis anterior tendon transfer in ambulatory children with spastic cerebral palsy with dynamic equinovarus fore foot according to Garceau and Palmer criteria. However, several methods are available for split tibialis transfer we think this is the best method for correction equino varus deformity in children with spastic cerebral palsy. A dynamic varus deformity can be treated by split tendon transfer to the outer side of the foot (only half of the tendon is transferred to avoid the risk overcorrection into valgus) ${ }^{2}$.

\section{Methods}

This is prospective case series study done on 13 ambulatory children with spastic cerebral palsy, 13 feet with dynamic equino varus fore foot and mid foot deformities, between March 2015 and April 2019. The mean follow up was 2.9 years. Their age ranged from 4-8 years, average 4.9 years. Males to female ratio were $(7: 6)$.

In three of them the other foot is just equinus deformity treated by concomitant percutaneous elongation of tendoachillis. Four of them presented with rigid equinovarus due to ankle contracture preoperative serial casting done for 6 weeks at 2 weeks intervals till they became supple. The static deformity will changed to dynamic deformity, equinovarus, then to control muscles imbalance and prevent recurrence we did split tibialis anterior tendon transfer (STATT).

\section{Surgical Procedure}

Chance of infection of the surgical procedure is minimized by giving third generation Cephalosporin "Cefotaxime $250 \mathrm{mg}$ i. v." before application of tourniquet after performing sensitivity test. Non touch technique is used during the surgical procedure and post operatively Cefixime suspension is given orally for three days. Under general anaesthesia, supine position, under pneumatic tourniquet control a 3 centimetre longitudinal incision was done along the course of tibialis anterior tendon from the inferior margin of the extensor retinaculum to its distal insertion on the medial cuneiform and first metatarsal bone. Dorsalis pedis artery was protected. The second incision done over the anterior aspect of the leg at musculotendinous junction, anterior tibial tendon is identified; umbilical tape is passed into the second incision Figure one. The medial half of the tendon was left attached to the first metatarsal and first cuneiform, but the lateral half was detached from its insertion by using scalpel_blade 11 which has a sharp tip which is very good for this procedure, whip stitch suture technique is used for securing the detached lateral half of the tibialis anterior tendon, the suture material was strong No.1 slowly absorbable monofilament suture material Polydioxanone suture (PDS). The third incision made over the third cuneiform (which is along the third metatarsal bone) image intensifier is used to confirm the third cuneiform and the lateral half of the tendon passed under the extensor retinaculum into the third incision. A hole drilled in the third cuneiform from dorsal to plantar surface usually we used a drill bit with $4.5 \mathrm{~mm}$ in diameter and sometimes the hole was widened slightly with a large curette, to became the same diameter of the tendon. A subcutaneous tunnel was created between the first and second incisions, keeping the transferred lateral half of tendon and to pull out from first to second incision. The tendon passed under the extensor retinaculum and finally 
through the drilled hole and withdrawn from the plantar surface of the foot and sutured tightly under tension outside the skin over a gauze sponge while the foot is placed in plantigrade position Figure two. Stability of the tendon is improved by suturing the tendon to the periosteum and surrounding soft tissue. The tourniquet was deflated, any bleeding is controlled and the incisions closed Figure three. Below knee P.O.P cast was applied in 9 of the cases, while in 4 of them with associated equinus deformities and concomitant percutaneous elongation of tendoachillis, the P.O.P. cast extended to above knee in 90 degrees flexion position. Postoperatively, the patients were allowed to weight bear as tolerated, the cast was removed at 6 weeks postoperatively. The patients were then followed at 3 months intervals for one year. Then 6 months intervals for 2 years and then we informed the family that the follow up should be continued annually till skeletal maturity.

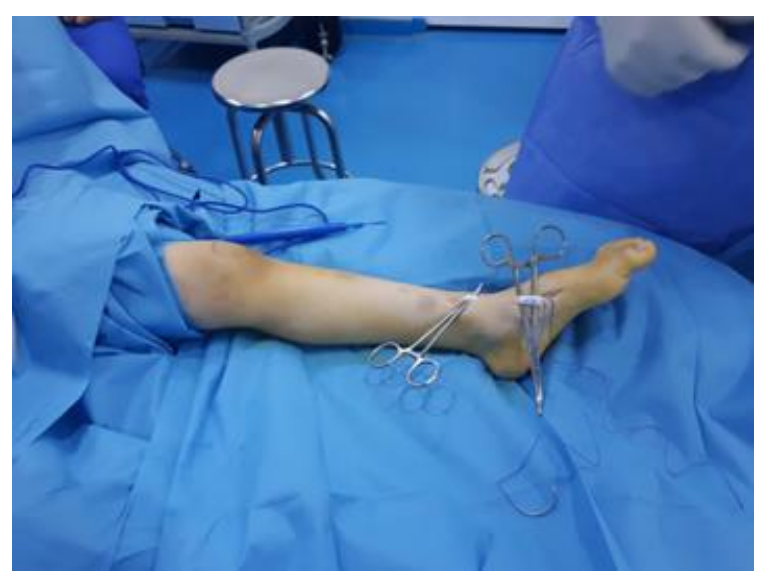

Figure (1) the first and second incisions were done for detaching of lateral half of tibialis anterior

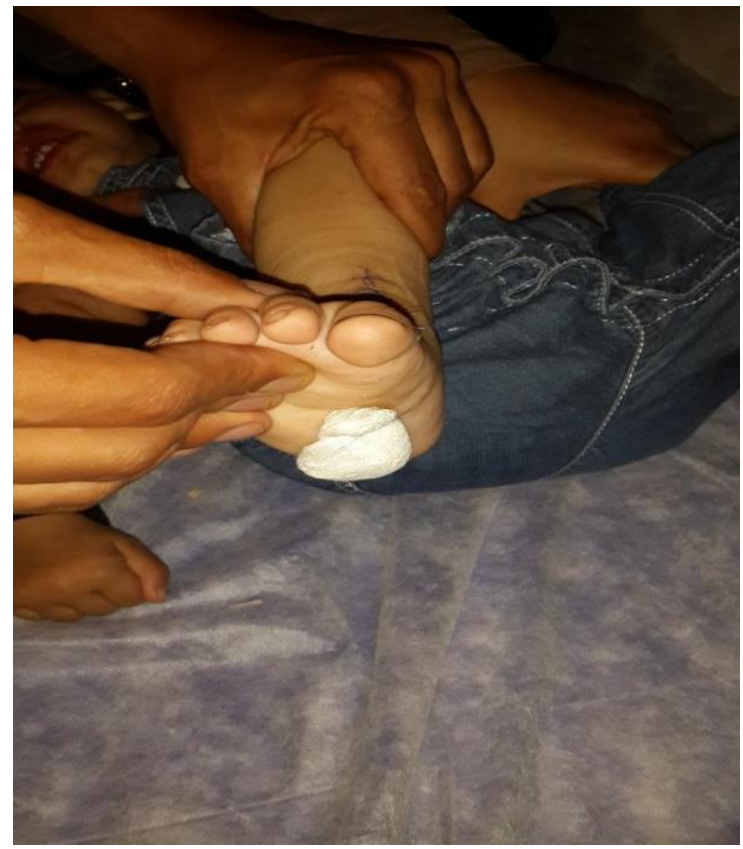

Figure (2) the suture was tightened and ligated on the gauze sponge in neutral position of the foot.

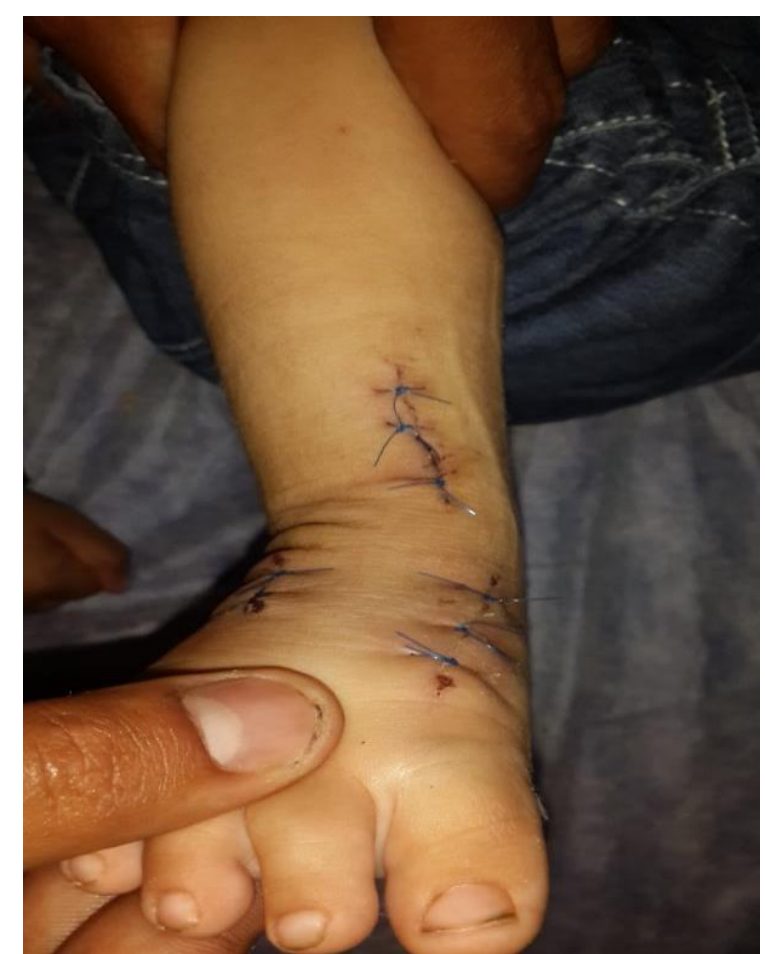

Figure (3) shows the location of the three incisions in the foot anteriorly. 


\section{Results}

The results are summarized in Table 1 in which 6 of the cases were male and 7 of them were female their age ranged from 4-8 years and average is 4.9 years. The results were assessed according to Garceau and Palmer criteria, which is based on the presence or absences of metatarsus adductus, heel varus and equinus, clinical appearance according to Garceau and Palmer criteria improved from 1.54 points preoperatively to 3.08 points postoperatively.

According to Table 2 in which the results were assessed by Garceau and Palmer criteria, 7 of the preoperatively were fair, and 6 of them were poor while postoperatively 2 of them became excellent 10 of them good while 1 of them was fair.

\begin{tabular}{|l|l|l|l|l|l|l|}
\hline \multicolumn{6}{|c|}{ Table 1 age and gender distribution of the cases, pre and post-operative garceau } \\
\hline $\begin{array}{c}\text { Series } \\
\text { No. }\end{array}$ & $\begin{array}{c}\text { Age in } \\
\text { years }\end{array}$ & Gender & $\begin{array}{r}\text { Preoperative } \\
\text { scoring }\end{array}$ & \multicolumn{2}{c|}{$\begin{array}{r}\text { Postoperative } \\
\text { scoring }\end{array}$} \\
\hline 1 & 4 & Female & Fair & 2 & Good & 3 \\
\hline 2 & 5 & Female & Fair & 2 & Excellent & 4 \\
\hline 3 & 6 & Female & Poor & 1 & Good & 3 \\
\hline 4 & 5 & Male & Poor & 1 & Good & 3 \\
\hline 5 & 4 & Female & Poor & 1 & Good & 3 \\
\hline 6 & 5 & Male & Poor & 1 & Good & 3 \\
\hline 7 & 4 & Male & Fair & 2 & Good & 3 \\
\hline 8 & 6 & Male & Fair & 2 & Good & 3 \\
\hline 9 & 8 & Female & Fair & 2 & Good & 3 \\
\hline 10 & 4 & Male & Fair & 2 & Good & 3 \\
\hline 11 & 5 & Male & Fair & 2 & Good & 3 \\
\hline 12 & 4 & Female & Poor & 1 & Excellent & 4 \\
\hline 13 & 4 & Female & Poor & 1 & Fair & 2 \\
\hline
\end{tabular}

\begin{tabular}{|c|c|c|c|c|}
\hline $\begin{array}{l}\text { Garceau and Palmer } \\
\text { criteria }\end{array}$ & $\begin{array}{l}\text { Preope } \\
\text { rative } \\
\text { No. of } \\
\text { the } \\
\text { patient } \\
\text { s }\end{array}$ & $\begin{array}{l}\text { Preopera } \\
\text { tive } \\
\text { Garceau } \\
\text { and } \\
\text { Palmer } \\
\text { scoring }\end{array}$ & $\begin{array}{l}\text { Postoper } \\
\text { ative } \\
\text { No. of } \\
\text { the } \\
\text { patients }\end{array}$ & $\begin{array}{l}\text { Postoper } \\
\text { ative } \\
\text { Garceau } \\
\text { and } \\
\text { Palmer } \\
\text { scoring }\end{array}$ \\
\hline Excellent ( 4 points ) & 0 & & 2 & 8 points \\
\hline Good ( 3 points ) & 0 & & 10 & 30 points \\
\hline Fair ( 2 points ) & 7 & $\begin{array}{c}14 \\
\text { points }\end{array}$ & 1 & 2 points \\
\hline Poor ( 1 point ) & 6 & 6 points & 0 & \\
\hline Total & 13 & $\begin{array}{c}20 \\
\text { points }\end{array}$ & 13 & 40 points \\
\hline Mean & & $\begin{array}{c}1.54 \\
\text { points }\end{array}$ & & $\begin{array}{c}3.08 \\
\text { points }\end{array}$ \\
\hline
\end{tabular}

\section{Discussion}

This prospective case series study on 13 feet of 13 ambulatory children with spastic cerebral palsy complaining from dynamic equinovarus deformity, by doing STATT, which is considered to be more effective than full tibialis anterior tendon transfer, as it is distributing equally the muscle power eliminating the possibility of residual deformity or over action similar to the study done by, Vlachou M, and Dimitris Dimitriadis ${ }^{10}$.We passed the transferred lateral half of tibialis anterior tendon under the extensor retinaculum, the advantage of this technique is that it preserve it's normal mechanism and prevents the tendon from bowstring when the foot is dorsiflexed, while the subcutaneous transfer cosmetically displeasing and may cause skin irritation when it rubs against the shoes .similar to the studies done Thompson et al., Abdel-AAI $\mathrm{M}$ et al. ${ }^{11,12}$. We transferred the lateral half of tibialis anterior tendon to the third cuneiform in contrast to the study done by Hoffer et al., which he was transferring to the cuboid ${ }^{9,10}$ because the third cuneiform is more medially located than cuboid, so there will be less tension on the 
tendon. Our method is similar to the study done by Kou et al. ${ }^{10}$.

The risk of tendon pull out is minimized by double fixation technique in which at the entry site of the tendon to the 3rd cuneiform by suturing to the periosteum and surrounding soft tissues and on the sole of the foot outside the skin the tendon is tight on a gauze, this differs from the study done by Agrawal A.K $\mathrm{K}^{9}$. In which he used Bio-Tenodesis absorbable interference screw, as we have shortage of this implant, and our method is costless.

\section{Conclusion:}

Split tibialis anterior tendon transfer is a good method for treating ambulatory children with spastic cerebral palsy complaining from dynamic equinovarus deformity of forefoot and midfoot which is due to over activity of the tibialis anterior muscle and weak antagonist.

Conflict of interest: The authors declare no conflict of interest.

Financial Support: None declared.

\section{References}

Abbaskhanian A, Rashedi V, Delpak A, Vameghi

$\mathrm{R}$, Gharib M. Rehabilitation interventions for children with cerebral palsy: a systematic review. Journal of Pediatrics Review. 2015 Jan 10; 3(1):0, http://dx.doi.org/10.5812/jpr.361.

2. Paley A. Graham, and Solomon L. Apley. "Solomon's System of Orthopaedics and Trauma. U: Blom A., Warwick D, Whitehouse MR Deseto izdanje." $10^{\text {th }}$ edition 2018 , chapter 10 , p. 240253.

3. Abel, Mark F., Diane L. Damiano, Michael Pannunzio, and Jeffrey Bush. "Muscletendon surgery in diplegic cerebral palsy: functional and mechanical changes." Journal of
Pediatric Orthopaedics 19, no. 3 (1999): 366375.

4. Kyllerman M, Bager B, Bensch J, Bille B, Olow I, Voss H. Dyskinetic cerebral palsy: I. Clinical categories, associated neurological abnormalities and incidences. Acta Paediatrica. 1982 Jul; 71(4):543-50, http://dx.doi.org/10.1111/j.16512227.1982.tb09472.x.

5. Blair E, Watson L. Epidemiology of cerebral palsy. In Seminars in Fetal and Neonatal Medicine 2006 Apr 1 (Vol. 11, No. 2, pp. 117125). WB Saunders.

6. Tugui RD, Antonescu D. Cerebral palsy gait, clinical importance. Maedica. 2013 Sep; 8(4):388.

7. Sankar C, Mundkur N. Cerebral palsydefinition, classification, etiology and early diagnosis. The Indian Journal of Pediatrics. 2005 Oct $\quad 1 ; \quad 72(10): 865-8$, http://dx.doi.org/10.1007/BF02731117.

8. Raju TN. Historical Perspectives: Perinatal Profiles: William Little and Cerebral Palsy. NeoReviews. 2006 Nov 1; 7(11):e567-8, http://dx.doi.org/10.1542/neo.7-11-e567.

9. Agarwal AK. Step by Step management of clubfoot by Ponseti technique. Jaypee Brothers Medical Publishers. 2007:1-92.

10. Vlachou M, Dimitriadis D. Split tendon transfers for the correction of spastic varus foot deformity: a case series study. Journal of Foot and Ankle Research. 2010 Dec; 3(1):1-1.

11. Thompson GH, Hoyen HA, Barthel T. Tibialis anterior tendon transfer after clubfoot surgery. Clinical orthopaedics and related research. 2009 May 1; 467(5):1306-13, http://dx.doi.org/10.1007/s11999-009-0757-2.

12. Abdel-AAl M, Abdel-Hamid SK, AbdelAleem S, Kornah B, Abdel-hamid MA. 
Correction of residual metatarsus adductus deformity following ponseti management of idiopathic clubfoot in toddlers by tibialis anterior tendon transfer. MOJ Orthop Rheumatol. 2017; 9(1):00344.

13. El-Fadl SM. Split versus full tibialis anterior tendon transfer in treatment of residual dynamic supination in treated idiopathic clubfoot by Ponseti method. The Egyptian Orthopaedic Journal. 2018 Apr 1; 53(2):147, http://dx.doi.org/10.4103/eoj.eoj_43_18. 